Jurnal Kesehatan Lingkungan Indonesia

http://ejournal.undip.ac.id/index.php/jkli

\title{
Hubungan Kadar Timbal Dalam Darah Dengan Tekanan Darah Pada Tenaga Kerja Di Karoseri Semarang
}

\author{
Association Between Blood Lead Levels And Blood Pressure Workers of Carroseri \\ Semarang
}

\author{
Mutasir $^{1}$, Onny Setiani², Sulistiyani² \\ ${ }^{1}$ Kantor Kesehatan Pelabuhan Banda Aceh \\ ${ }^{2}$ Program Magister Kesehatan Lingkungan Fakultas Kesehatan Masyarakat, Universitas Diponegoro
}

Info Artikel : Diterima Maret 2016 ; Disetujui April 2016 ; Publikasi April 2016

\begin{abstract}
Background: Lead is a toxic metal that can be contained in paint as a source of lead exposure in the air so significantly associated with blood lead levels (BLL). Statistically there is a significant association between BLL and blood pressure (BP). Preliminary study found that 10 workers of Carroseri Semarang found that 8 people (80\%) had BLL above the threshold value, 7 people (70\%) had a systolic blood pressure (SBP) above the limit normal and 8 people (80\%) had diastolic blood pressure (DBP) at the upper limit of normal.

Objective: This study aimed to determine the association between BLL and BP workers of Carroseri Semarang.

Methods: It was an observational study with cross sectional approach. The population of this research was workers of Carroseri Semarang with a sample size of 34 people. Data collected by examining the levels of lead in paint, inspection level of lead in the air, checking blood lead levels and blood pressure checks.

Results: This study showed the average level of lead in the paint measured was 59.39 ppm, level of lead in the air $0.002 \mathrm{ppm}$, BLL $28.97 \mathrm{mg} / \mathrm{dL}$, SBP $122.76 \mathrm{mmHg}$ and DBP $79.06 \mathrm{mmHg}$.

Conclusion: All types of paint used in Carroseri Semarang contain lead under TLVS 600 ppm, the ambient workspace containing air lead levels below TLVS 0.05 ppm, the entire workforce part painting has undergone blood lead exposure $>5 \mu \mathrm{g} / \mathrm{dL}$, there is no association between $B L L$ and $S B P(p=0.465)$ and there a association between BLL and DBP $(p=0.030)$.
\end{abstract}

Keywords: lead paint, blood lead levels, systolic blood pressure, diastolic blood pressure.

\section{PENDAHULUAN}

Timbal adalah logam beracun yang banyak digunakan dan telah menyebabkan berbagai masalah pencemaran lingkungan dan kesehatan. ${ }^{1}$ Timbal adalah logam beracun yang dapat terkandung dalam cat. $^{2}$ Costumer Product Safety Commission (CPSC) menetapkan bahwa kadar timbal dalam cat sebesar 600 ppm. Ditempat kerja, biasanya timbal masuk ke dalam tubuh melalui inhalasi, ingesti atau dermal contact bahan bahan kimia yang mengandung partikel timbal. $^{3}$

The National Health And Medical Research Council (NHMCR) menetapkan bahwa kadar timbal $>10 \mathrm{mg} / \mathrm{dL}$ dapat berpengaruh terhadap tekanan darah, ginjal, sel-sel darah, otak dan sistem saraf. ${ }^{4}$ Centers for Disease Control and Prevention (CDC) menyatakan bahwa standar tekanan darah normal (sistolik $<120 \mathrm{mmHg}$ dan diastolik $<80 \mathrm{mmHg}$ ), berisiko/ prehipertensi (sistolik 120-139 mmHg dan diastolik 80-89 $\mathrm{mmHg}$ ), tekanan darah tinggi (sistolik $\geq 140 \mathrm{mmHg}$ dan diastolik $\geq 90 \mathrm{mmHg}$ ). ${ }^{5}$ World Health Organization (WHO) menyatakan bahwa sekitar 22\% dari orang dewasa berusia $\geq 18$ tahun telah mengalami peningkatan tekanan darah pada tahun $2014 .^{6}$ sekitar 70 juta orang dewasa Amerika (29\%) memiliki tekanan darah tinggi yang merupakan penyebab utama atau memberikan kontribusi kematian $>360.000$ orang pada tahun 2013.5 Di Indonesia, 25,8\% penduduk menderita penyakit hipertensi dan sampai saat ini hipertensi masih merupakan tantangan besar masalah kesehatan dengan prevalensi yang tinggi. ${ }^{7}$ Kasus hipertensi essensial di Propinsi Jawa Tengah pada tahun 2012 sebesar 544.771 kasus. $^{8}$

Hasil penelitian Muliyadi, dkk menunjukkan bahwa penggunaan cat yang mengandung timbal pada 
kegiatan pengecatan mobil di Surabaya menyebabkan tingginya timbal di udara $(0,065372 \mathrm{ppm}>\mathrm{NAB} 0,05$ ppm). Semakin tinggi paparan timbal di udara maka semakin tinggi pula kadar timbal darah (rata-rata kadar timbal dalam darah 11,20 $\mu \mathrm{g} / \mathrm{dL}, \mathrm{p}=0,000)$, artinya ada pengaruh kadar timbal di udara terhadap kadar timbal darah. ${ }^{9}$

Secara statistik terdapat hubungan signifikan antara tingkat kadar timbal dalam darah dengan tekanan darah sistolik dan diastolik. ${ }^{10}$ Hasil penelitian Fenga $\mathrm{C}$, et al. pada pekerja pabrik baterai bekas diketahui bahwa rata-rata kadar timbal dalam darah pekerja $42,33 \mu \mathrm{g} / \mathrm{dL}$, rata-rata tekanan darah sistolik $129,85 \mathrm{mmHg}$ dan rata-rata tekanan darah diastolik $80,56 \mathrm{mmHg}$ (p-value $=0,02$ ), artinya pemaparan timbal dengan kadar rendah yang lama secara kumulatif akan meningkatkan tekanan darah. ${ }^{11}$

Berdasarkan hasil pemeriksaan pendahuluan terhadap 10 orang tenaga kerja di Karoseri Semarang dapat diketahui bahwa rata-rata kadar timbal dalam darah tenaga kerja yang diperiksa sebesar $35,317 \mu \mathrm{g} / \mathrm{dL}$. Sebanyak 8 orang $(80 \%)$ memiliki kadar timbal dalam darah di atas nilai ambang batas yang dapat meningkatkan tekanan darah. Rata-rata tekanan darah sistolik sebesar $125 \mathrm{mmHg}$ dan rata-rata tekanan darah diastolik sebesar $82 \mathrm{mmHg}$. Sebanyak 7 orang $(70 \%)$ tenaga kerja memiliki tekanan darah sistolik di atas batas tekanan darah normal dan sebanyak 8 orang $(80 \%)$ tenaga kerja memiliki tekanan darah diastolik di atas batas tekanan darah normal.

Tujuan penelitian ini adalah untuk mengetahui hubungan antara kadar timbal dalam darah dengan tekanan darah pada tenaga kerja di Karoseri Semarang?

\section{METODE PENELITIAN}

Jenis penelitian ini merupakan penelitian observasional dengan menggunakan pendekatan cross-sectional. ${ }^{12}$ Pemeriksaan kadar timbal dalam cat dilakukan di Laboratorium Pengujian Balai Besar Teknologi Pencegahan Pencemaran Industri (BBTPPI) Semarang. Pengambilan sampel udara dengan metode gravimetri untuk debu (partikel) dengan menggunakan peralatan high volume air sampler (HVAS) dan pemeriksaan kadar timbal dalam udara menggunakan metoda atomic absorbtion spectrophotometer (AAS) yang dilakukan oleh petugas Balai Laboratorium Kesehatan Propinsi Jawa Tengah. Pemeriksaan tekanan darah dilakukan dengan cara auskultasi menggunakan alat sfigmomanometer air raksa dan stetoskop. $^{13}$

Penimbangan berat badan dilakukan dengan menggunakan timbangan injak dan pengukuran tinggi badan menggunakan meter ukur. ${ }^{14,15}$ Pemeriksaan kadar timbal dalam darah di laksanakan di Laboratorium GAKI Fakultas Kedokteran Universitas Diponegoro Semarang dengan menggunakan metoda AAS.
Populasi dalam penelitian ini adalah seluruh tenaga kerja yang berhubungan langsung dengan bahan dasar cat yaitu sebanyak 50 orang yang terdiri 25 orang tenaga kerja bagian epoxy primer (epoxy primer, epoxy filler, epoxy interior dan dashboard ending) dan 25 orang tenaga kerja bagian stripping (base coat, stripping dan pengecatan AC). Berdasarkan rumus Lemeshow didapatkan jumlah sampel dalam penelitian ini adalah sebanyak 34 orang. ${ }^{16}$ Dalam penelitian ini juga dilakukan pengambilan sampel cat sebanyak 16 sampel dan pengambilan sampel udara sebanyak 5 titik pengukuran.

\section{HASIL DAN PEMBAHASAN}

Berdasarkan tabel 1 diketahui rata-rata kadar timbal dalam cat yang digunakan pada bagian pengecatan di Karoseri Semarang adalah sebesar 59,39 ppm dengan kadar timbal dalam cat tertinggi 192,25 ppm dan terendah 7,77 ppm.

Berdasarkan tabel 2 diketahui rata-rata kadar timbal dalam udara ruang kerja pengecatan mobil di Karoseri Semarang sebesar $0,002 \mathrm{mg} / \mathrm{m}^{3}$ dengan kadar timbal udara tertinggi sebesar $0,0077 \mathrm{mg} / \mathrm{m}^{3}$ dan terendah sebesar $0,0013 \mathrm{mg} / \mathrm{m}^{3}$.

Tabel 3 menunjukkan rata-rata usia tenaga kerja di Karoseri Semarang 37,15 tahun dengan standar deviasi 10,91, rata-rata kadar timbal dalam darah $28,97 \mu \mathrm{g} / \mathrm{dL}$ dengan standar deviasi 19,19, rata-rata tekanan darah sistolik $122,76 \mathrm{mmHg}$ dengan standar deviasi 15,80 dan rata-rata tekanan darah diastolik 79,06 mmHg dengan standar deviasi 10,65.

Berdasarkan tabel 4 diketahui proporsi tenaga kerja dengan tekanan darah sistolik tidak normal pada kelompok kadar timbal yang tinggi dalam darah $(56,5 \%)$ lebih kecil dibandingkan proporsi tenaga kerja dengan tekanan darah sistolik tidak normal pada kelompok kadar timbal dalam darah rendah $(72,7 \%)$. Hasil uji Chi-Square diperoleh nilai $p>0,05$, $(\mathrm{PR}=0,777,95 \% \mathrm{CI}=0,47-1,29)$, artinya tidak ada hubungan yang bermakna antara kadar timbal dalam darah dengan tekanan darah sistolik. Berdasarkan tabel 5 diketahui bahwa tidak ada hubungan antara usia dengan tekanan darah sistolik pada tenaga kerja di Karoseri Semarang (nilai- $p=0,251 ; \quad \mathrm{PR}=1,477$; $\mathrm{CI}=0,91-2,39$ ). Tidak ada hubungan antara riwayat keturunan hipertensi dengan tekanan darah sistolik pada tenaga kerja di Karoseri Semarang (nilai$p=0,513 ; \quad \mathrm{PR}=1,684 ; \quad \mathrm{CI}=1,27-2,24) . \quad$ Tidak ada hubungan antara indeks massa tubuh dengan tekanan darah sistolik pada tenaga kerja di Karoseri Semarang (nilai- $p=0,627 ; \mathrm{PR}=1,265 ; \mathrm{CI}=0,80-2,33$ ). Tidak ada hubungan antara kebiasaan merokok dengan tekanan darah sistolik pada tenaga kerja di Karoseri Semarang (nilai- $p=0,427 ; \mathrm{PR}=0,908 ; \mathrm{CI}=0,45-1,83$ ). Tidak ada hubungan antara kebiasaan konsumsi alkohol dengan tekanan darah sistolik pada tenaga kerja di Karoseri Semarang (nilai- $p=1,000 ; \mathrm{PR}=2,551 ; \mathrm{CI}=0,94-6,95$ ). Tidak ada hubungan antara kebiasaan berolahraga dengan tekanan darah sistolik pada tenaga kerja di Karoseri Semarang (nilai- $p=0,704 ; \quad \mathrm{PR}=1,200$; $\mathrm{CI}=0,71-2,04)$. 
Berdasarkan tabel 5 diketahui proporsi tenaga kerja dengan tekanan darah diastolik tidak normal pada kelompok kadar timbal yang tinggi dalam darah $(69,6 \%)$ lebih besar dibandingkan proporsi tenaga kerja dengan tekanan darah diastolik tidak normal pada kelompok kadar timbal dalam darah rendah (27,3\%). Hasil uji Chi-Square diperoleh nilai $p<0,05$, $(\mathrm{PR}=2,55,95 \% \mathrm{CI}=0,94-6,95)$, artinya ada hubungan yang bermakna antara kadar timbal dalam darah dengan tekanan darah diastolik. Berdasarkan tabel 5 dapat juga diketahui tidak ada hubungan antara usia dengan tekanan darah diastolik pada tenaga kerja di Karoseri Semarang (nilai- $p=0,451 ; \quad \mathrm{PR}=1,400$; $\mathrm{CI}=0,79-2,48)$. Tidak ada hubungan antara riwayat keturunan hipertensi dengan tekanan darah diastolik pada tenaga kerja di Karoseri Semarang (nilai- $p=0,492 ; \quad \mathrm{PR}=1,882 ; \quad \mathrm{CI}=1,36-2,61) . \quad$ Tidak $\quad$ ada hubungan antara indeks massa tubuh dengan tekanan darah diastolik pada tenaga kerja di Karoseri Semarang (nilai- $p=1,000 ; \mathrm{PR}=1,088 ; \mathrm{CI}=0,49-2,39$ ). Tidak ada hubungan antara kebiasaan merokok dengan tekanan darah diastolik pada tenaga kerja di Karoseri Semarang (nilai- $p=0,240 ; \quad \mathrm{PR}=0,617$; $\mathrm{CI}=0,36-1,06)$. Tidak ada hubungan antara kebiasaan konsumsi alkohol dengan tekanan darah diastolik pada tenaga kerja di Karoseri Semarang (nilai- $p=0,426$; $\mathrm{PR}=1,378 ; \mathrm{CI}=0,76-2,49)$. Tidak ada hubungan antara kebiasaan berolahraga dengan tekanan darah diastolik pada tenaga kerja di Karoseri Semarang (nilai$p=1,000 ; \mathrm{PR}=1,108 ; \mathrm{CI}=0,59-2,07)$.

Tabel 1. Hasil Pemeriksaan Kadar Timbal Dalam Cat Yang Digunakan di Karoseri Semarang

\begin{tabular}{clc}
\hline No & \multicolumn{1}{c}{ Warna Cat } & Kadar Timbal (ppm) \\
\hline 1 & Abu-abu (primer grey) & 15,03 \\
2 & Abu-abu (filler grey) & 15,16 \\
3 & Abu-abu tua (grey LKS) & 77,27 \\
4 & Coklat (F3 brown) & 105,9 \\
5 & Hitam (black stone grey) & 38,72 \\
6 & Coklat (primer brown) & 45,68 \\
7 & Putih (white solid) & 7,99 \\
8 & Kuning (yellow solid) & 101,8 \\
9 & Merah (signal red solid) & 142,5 \\
10 & Biru (blue solid) & 57,83 \\
11 & Hitam (black solid) & 53,46 \\
12 & Putih (white peal metalicl) & 16,54 \\
13 & Orange (sunkis metalic) & 61,94 \\
14 & Merah (red metalic) & 192,25 \\
15 & Biru (curako blue metalic) & 7,77 \\
16 & Hitam (black metalic) & 10,38 \\
& Rata-rata & 59,39 \\
\hline
\end{tabular}

Tabel 2. Hasil Pemeriksaan Kadar Timbal Udara Lingkungan Kerja di Karoseri Semarang

\begin{tabular}{clccc}
\hline No & Titik Sampel & Kadar Timbal Udara & Permenakertrans & Kesimpulan \\
\hline 1 & Bagian Pendempulan & $0,0018 \mathrm{mg} / \mathrm{m}^{3}$ & $0,05 \mathrm{mg} / \mathrm{m}^{3}$ & Di bawah NAB \\
2 & Bagian Epoxy Primer & $0,0018 \mathrm{mg} / \mathrm{m}^{3}$ & $0,05 \mathrm{mg} / \mathrm{m}^{3}$ & Di bawah NAB \\
3 & Bagian Stripping & $0,0077 \mathrm{mg} / \mathrm{m}^{3}$ & $0,05 \mathrm{mg} / \mathrm{m}^{3}$ & Di bawah NAB \\
4 & Bagian Epoxy Interior & $0,0014 \mathrm{mg} / \mathrm{m}^{3}$ & $0,05 \mathrm{mg} / \mathrm{m}^{3}$ & Di bawah NAB \\
5 & Bagian Base coat & $0,0013 \mathrm{mg} / \mathrm{m}^{3}$ & $0,05 \mathrm{mg} / \mathrm{m}^{3}$ & Di bawah NAB \\
& Rata-rata & $0,002 \mathrm{mg} / \mathrm{m}^{3}$ & & \\
\hline
\end{tabular}

Tabel 3. Karakteristik Responden

\begin{tabular}{clccccc}
\hline No & Variabel & Min & Mak & Mean & Median & SD \\
\hline 1 & Usia (Tahun) & 21 & 54 & 37,15 & 37,50 & 10,91 \\
2 & Kadar Timbal Darah $(\mu \mathrm{g} / \mathrm{dL})$ & 5,09 & 68,43 & 28,97 & 26,19 & 19,19 \\
3 & Indeks Massa Tubuh $\left(\mathrm{kg} / \mathrm{m}^{2}\right)$ & 15,60 & 29,80 & 21,56 & 21,30 & 3,69 \\
4 & Tekanan Sistolik $(\mathrm{mmHg})$ & 90 & 160 & 122,76 & 120 & 15,80 \\
5 & Tekanan Diastolik $(\mathrm{mmHg})$ & 52 & 100 & 79,06 & 80 & 10,65 \\
\hline
\end{tabular}


Tabel 4. Hasil Uji Beda Proporsi Variabel Kadar Timbal Dalam Darah, Usia, Riwayat Keturunan Hipertensi, IMT, Kebiasaan Merokok, Kebiasaan Konsumsi Alkohol dan Kebiasaan Berolahraga Dengan Tekanan Darah Sistolik Pada Tenaga Kerja di Karoseri Semarang

\begin{tabular}{|c|c|c|c|c|c|}
\hline \multirow[t]{2}{*}{ No } & \multirow[t]{2}{*}{ Variabel } & \multicolumn{2}{|c|}{ Tekanan Darah Sistolik } & \multirow{2}{*}{$\begin{array}{c}\text { RP } \\
(95 \% \mathrm{CI})\end{array}$} & \multirow[t]{2}{*}{ Nilai- $p$} \\
\hline & & $\begin{array}{c}\text { Tidak Normal } \\
(\%)\end{array}$ & Normal (\%) & & \\
\hline \multirow[t]{3}{*}{1} & Kadar Timbal Dalam Darah & & & & \\
\hline & Tinggi $(n=23)$ & $13(56,5)$ & $10(43,5)$ & $0,777 \quad(0,47-1,29)$ & $0,465^{\mathrm{c}}$ \\
\hline & Rendah (n=11) & $8(72,7)$ & $3(38,2)$ & & \\
\hline \multirow[t]{3}{*}{2} & Usia & & & & \\
\hline & $>45$ Tahun $(\mathrm{n}=10)$ & $8(80,0)$ & $2(20,0)$ & 1,477 & $0,251^{\mathrm{c}}$ \\
\hline & $\leq 45$ Tahun $(\mathrm{n}=24)$ & $13(54,2)$ & $11(45,8)$ & $(0,91-2,39)$ & \\
\hline \multirow[t]{3}{*}{3} & Riwayat Keturunan Hipertensi & & & & \\
\hline & $\mathrm{Ya}(\mathrm{n}=2)$ & $2(100)$ & $0(0)$ & 1,684 & $0,513^{\mathrm{c}}$ \\
\hline & Tidak $(\mathrm{n}=32)$ & $19(59,4)$ & $13(40,6)$ & $(1,27-2,24)$ & \\
\hline \multirow[t]{3}{*}{4} & Indeks Massa Tubuh (IMT) & & & & \\
\hline & IMT Berlebih $(\mathrm{n}=5)$ & $4(80,0)$ & $1(20,0)$ & 1,265 & $0,627^{\mathrm{c}}$ \\
\hline & Normal $(n=29)$ & $17(58,6)$ & $12(41,4)$ & $(0,80-2,33)$ & \\
\hline \multirow[t]{3}{*}{5} & Kebiasaan Merokok & & & & \\
\hline & $\mathrm{Ya}(\mathrm{n}=25)$ & $14(56,0)$ & $11(44,0)$ & 0,908 & $0,427^{\mathrm{c}}$ \\
\hline & Tidak $(\mathrm{n}=9)$ & $7(77,8)$ & $2(22,2)$ & $(0,45-1,83)$ & \\
\hline \multirow[t]{3}{*}{6} & Kebiasaan Konsumsi Alkohol & & & & \\
\hline & $\mathrm{Ya}(\mathrm{n}=7)$ & $4(57,1)$ & $3(42,9)$ & 2,551 & $1,000^{\mathrm{c}}$ \\
\hline & Tidak $(n=27)$ & $17(63,0)$ & $10(37,0)$ & $(0,94-6,95)$ & \\
\hline \multirow[t]{3}{*}{7} & Kebiasaan Olah Raga & & & & \\
\hline & Tidak $(\mathrm{n}=10)$ & $7(70,0)$ & $3(30,0)$ & 1,200 & $0,704^{\mathrm{c}}$ \\
\hline & $\mathrm{Ya}(\mathrm{n}=24)$ & $14(58,3)$ & $10(41,7)$ & $(0,71-2,04)$ & \\
\hline
\end{tabular}

${ }^{\mathrm{c}}$ : Uji Chi-Square, *nilai-p<0,05 (significant)

Tabel 5.Hasil Uji Beda Proporsi Variabel Kadar Timbal Dalam Darah, Usia, Riwayat Keturunan Hipertensi, IMT, Kebiasaan Merokok, Kebiasaan Konsumsi Alkohol dan Kebiasaan Berolahraga Dengan Tekanan Darah Diastolik Pada Tenaga Kerja di Karoseri Semarang

\begin{tabular}{|c|c|c|c|c|c|}
\hline \multirow{2}{*}{ No } & \multirow{2}{*}{ Variabel } & \multicolumn{2}{|c|}{ Tekanan Darah Diastolik } & \multirow[t]{2}{*}{$\begin{array}{c}\text { RP } \\
(95 \% \mathrm{CI})\end{array}$} & \multirow[t]{2}{*}{ Nilai- $p$} \\
\hline & & $\begin{array}{c}\text { Tidak } \\
\text { Normal }(\%) \\
\end{array}$ & $\begin{array}{c}\text { Normal } \\
(\%)\end{array}$ & & \\
\hline \multirow[t]{3}{*}{1} & Kadar Timbal Dalam Darah & & & & \\
\hline & Tinggi $(n=23)$ & $16(69,6)$ & $7(30,4)$ & 2,551 & $0,030^{c}$ \\
\hline & Rendah $(\mathrm{n}=11)$ & $3(27,3)$ & $8(72,7)$ & $(0,94-6,95)$ & \\
\hline \multirow[t]{3}{*}{2} & Usia & & & & \\
\hline & $>45$ Tahun $(\mathrm{n}=10)$ & $7(70,0)$ & $3(30,0)$ & 1,400 & $0,451^{\mathrm{a}}$ \\
\hline & $\leq 45$ Tahun $(n=24)$ & $12(50,0)$ & $12(50,0)$ & $(0,79-2,48)$ & \\
\hline \multirow[t]{3}{*}{3} & Riwayat Keturunan Hipertensi & & & & \\
\hline & $\mathrm{Ya}(\mathrm{n}=2)$ & $2(100)$ & $0(0)$ & 1,882 & $0,492^{\mathrm{a}}$ \\
\hline & Tidak $(n=32)$ & $17(53,1)$ & $15(46,9)$ & $(1,36-2,61)$ & \\
\hline \multirow[t]{3}{*}{4} & Indeks Massa Tubuh (IMT) & & & & \\
\hline & IMT Berlebih $(\mathrm{n}=5)$ & $3(60,0)$ & $2(40,0)$ & 1,088 & $1,000^{\mathrm{a}}$ \\
\hline & Normal $(n=29)$ & $16(55,2)$ & $13(44,8)$ & $(0,49-2,39)$ & \\
\hline \multirow[t]{3}{*}{5} & Kebiasaan Merokok & & & & \\
\hline & $\mathrm{Ya}(\mathrm{n}=25)$ & $12(48,0)$ & $13(52,0)$ & 0,617 & $0,240^{\mathrm{a}}$ \\
\hline & Tidak $(\mathrm{n}=9)$ & $7(77,8)$ & $2(22,2)$ & $(0,36-1,06)$ & \\
\hline \multirow[t]{3}{*}{6} & Kebiasaan Konsumsi Alkohol & & & & \\
\hline & $\mathrm{Ya}(\mathrm{n}=7)$ & $5(71,4)$ & $2(28,6)$ & 1,378 & $0,426^{\mathrm{a}}$ \\
\hline & Tidak $(n=27)$ & $14(51,9)$ & $13(48,1)$ & $(0,76-2,49)$ & \\
\hline \multirow[t]{3}{*}{7} & Kebiasaan Olah Raga & & & & \\
\hline & Tidak $(n=10)$ & $6(60,0)$ & $4(40,0)$ & 1,108 & $1,000^{\mathrm{a}}$ \\
\hline & $\mathrm{Ya}(\mathrm{n}=24)$ & $13(54,2)$ & $11(45,8)$ & $(0,59-2,07)$ & \\
\hline
\end{tabular}

${ }^{\mathrm{c}}$ : Uji Chi-Square, *nilai-p<0,05 (significant) 
Hasil penelitian telah dapat memberikan informasi yang cukup menarik terhadap adanya paparan timbal dalam darah tenaga kerja dan adanya hubungan yang signifikan antara kadar timbal dalam darah dengan tekanan darah diastolik. Dalam penelitian ini juga dapat diketahui adanya kandungan timbal dalam cat yang digunakan dalam proses pengecatan sehingga akan sangat bermanfaat bagi tenaga kerja dalam pencegahan penyakit akibat kerja, bermanfaat bagi stakeholder di Karoseri Semarang dan instansi pemerintahan bidang kesehatan dalam pengambilan kebijakan untuk mengurangi paparan timbal terhadap tenaga kerja serta bermanfaat bagi peneliti kesehatan dalam pengambilan kebijakan dan penelitian lanjutan guna menentukan standar timbal dalam berbagai bahan yang digunakan di lingkungan kerja, standar paparan timbal yang diperbolehkan bagi kesehatan tenaga kerja dan standar kesehatan kadar timbal dalam darah yang sesuai dengan karakteristik masyarakat dan tenaga kerja Indonesia serta dampak yang ditimbulkannya

\section{A. Kadar Timbal Dalam Cat, Kadar Timba Udara dan Kadar Timbal Dalam}

Adanya paparan timbal dalam darah pada tenaga kerja bagian painting (pengecatan) dipengaruhi oleh berbagai faktor antara lain adanya kandungan timbal dalam bahan/ material yang digunakan dalam proses pengecatan, dalam hal ini adanya kandungan timbal dalam cat, adanya peningkatan paparan timbal dalam udara lingkungan kerja, lama paparan perhari, lama masa kerja dan adanya risiko pengecatan seperti penggunaan serta pemakaian alat pelindung diri. ${ }^{17}$

Hasil penelitian ini menunjukkan bahwa kandungan timbal dalam sampel cat yang digunakan di Karoseri Semarang masih berada di bawah standar kadar timbal dalam cat yang telah ditetapkan oleh CPSC dan Standar Nasional Indonesia (SNI) Nomor 8011 Tahun 2014 untuk kadar timbal dalam cat dekoratif berbasis pelarut organik sebesar 600 ppm. ${ }^{3,18}$ BaliFokus merekomendasikan kepada pemerintah dan badan-badan lain yang terkait agar membatasi kandungan timbal dalam cat yang diperjualbelikan atau di produksi di Indonesia setinggi-tingginya 90 bagian per juta (ppm) total berat kering. BaliFokus juga telah merekomendasikan kepada sektor swasta agar beralih ke bahan cat alternatif bebas timbal yang lebih aman dimana saat ini bahan-bahan pengganti telah tersedia di pasar dengan harga yang terjangkau. ${ }^{2}$

Menurut NSW Government Australia, penggunaan cat bebas timbal akhirnya akan dapat menghilangkan paparan dan risiko penyakit yang terkait dengan timbal. ${ }^{19}$ WHO dan United Nations Environment Programme (UNEP) melalui program The Global Alliance to Eliminate Lead Paint (Aliansi global menghilangkan timbal cat) juga telah membuat sebuah inisiatif baru untuk fokus dan mengkatalisasi berbagai upaya bagi pemangku kepentingan dalam mencapai tujuan internasional untuk mencegah paparan cat yang mengandung timbal bagi para pekerja yang akhirnya akan menghilangkan risiko paparan timbal dalam cat. $^{20}$

Hasil pemeriksaan kadar timbal udara di ruang kerja bagian dempul pengecatan di Karoseri Semarang masih di bawah NAB kadar timbal udara sesuai Perrmenakertrans nomor 13/Men/X/2011 yaitu 0,05 ppm. Beberapa faktor yang mempengaruhi rendahnya kadar timbal udara dalam penelitian ini antara lain kemungkinan disebabkan karena rendahnya kandungan timbal dalam cat yang digunakan di Karoseri Semarang, aktivitas pengecatan yang belum maksimal dilaksanakan pada triwulan pertama khususnya pada saat penelitian ini dilaksanakan, adanya kegiatan perbaikan peralatan di ruang kerja dempul painting sehingga ada beberapa bagian pekerjaan pengecatan belum dapat dilaksanakan secara maksimal, serta kemampuan alat pengukuran kualitas udara (HVAS) yang digunakan tidak mampu bekerja maksimal, sehingga hanya 5 titik sampel udara yang dapat dilakukan pengukuran dalam penelitian ini.

Hasil pengukuran kadar timbal dalam udara di Karoseri Semarang sedikit berbeda dengan hasil penelitian Muliyadi, dkk dimana diketahui bahwa kadar timbal udara di ruang pengecatan mobil di Surabaya sebesar $0,065372 \mathrm{ppm}$ dan telah melebihi NAB untuk timbal udara yang telah ditetapkan dalam Permenakertrans nomor 13/Men/X/2011 yaitu sebesar $0,05 \mathrm{ppm}$. Tingginya kadar timbal udara di ruang pengecatan mobil di Surabaya karena penggunaan cat yang mengandung timbal seperti timbal kromat, timbal kromat molibdat, dan timbal sulfat. Rata-rata kadar timbal dalam darah tenaga kerja pengecatan mobil di Surabaya sebesar $11,20 \mu \mathrm{g} / \mathrm{dL}$, artinya dapat dikatakan bahwa semakin tinggi paparan timbal di udara maka semakin tinggi pula kadar timbal darah. ${ }^{21}$

Adanya paparan timbal dalam darah tenaga kerja menunjukkan bahwa seluruh tenaga kerja bagian painting di Karoseri Semarang telah mengalami keracunan timbal dalam darah karena kadarnya telah melebihi batas keracunan timbal yang ditetapkan oleh WHO, CDC dan California departemen of public health $(\mathrm{CDPH})$ yaitu sebesar $5 \mu \mathrm{g} / \mathrm{dL} .^{22,23,24} \mathrm{NHMCR}$ menyatakan bahwa paparan timbal $>10 \mathrm{mg} / \mathrm{dL}$ dapat menimbulkan efek berbahaya bagi sejumlah fungsi tubuh dan organ orang dewasa mencakup efek pada tekanan darah. ${ }^{4}$ Hasil penelitian Fenga C, et al. juga menyatakan bahwa pemaparan timbal dengan kadar rendah dalam waktu yang lama secara kumulatif akan meningkatkan tekanan darah sistolik dan diastolik. ${ }^{11}$

Berbagai upaya harus dilakukan untuk mencegah dan menghindari efek toksik timbal. Terapi untuk para pekerja yang keracunan timbal dapat menggunakan

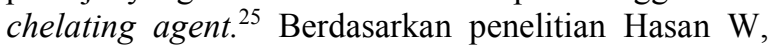
pemberian kalsium dengan dosis $3 \times 500 \mathrm{mg}$ perhari selama 3 bulan dapat menurunkan kadar timbal dalam darah secara bermakna sehingga dapat 
dipertimbangkan dipakai untuk menurunkan kadar timbal dalam darah pada orang dewasa. ${ }^{26}$

\section{B. Hubungan Kadar Timbal Dalam Darah Dengan Tekanan Darah Sistolik dan Tekanan Darah Diastolik}

Hasil penelitian ini membuktikan bahwa tidak ada hubungan antara kadar timbal dalam darah dengan tekanan darah sistolik dan penelitian ini telah dapat membuktikan adanya hubungan yang signifikan antara kadar timbal dalam darah dengan tekanan darah diastolik. Hasil penelitian ini membuktikan bahwa adanya kadar timbal yang tinggi dalam darah secara langsung akan mempengaruhi tekanan darah diastolik pada tenaga kerja di Karoseri Semarang dan bukan disebabkan oleh berbagai faktor perancu lain seperti riwayat keturunan hipertensi, indeks massa tubuh (IMT), kebiasaan merokok, kebiasaan mengkonsumsi alkohol dan kebiasaan berolahraga.

Adanya hubungan kadar timbal yang tinggi dalam darah dengan tekanan diastolik pada tenaga kerja di Karoseri Semarang juga membuktikan bahwa tenaga kerja telah mengalami toksisitas timbal secara kronis. Hal ini terbukti bahwa semua responden di Karoseri Semarang telah mengalami keracunan timbal walaupun dalam masa kerja $<5$ tahun. Penelitian ini sesuai dengan hasil penelitian Nawrot TS, dkk menyatakan bahwa peningkatan 2 kali konsentrasi timbal dalam darah berkaitan dengan peningkatan tekanan darah diastolik sebesar $0,7 \mathrm{mmHg} .{ }^{27}$ Adanya tenaga kerja yang memiliki kadar timbal dalam darah tinggi namun tidak menderita tekanan darah tinggi kemungkinan juga karena mengalami anemia. Hal ini berdasarkan pada hasil penelitian Turak, dkk yang menemukan adanya korelasi negatif antara kadar hemoglobin dengan tekanan darah sistolik $(\mathrm{r}=-0,289$, $\mathrm{p}=0,002){ }^{28}$

Beberapa mekanisme telah terbukti bahwa timbal berkontribusi pada patogenesis hipertensi antara lain: (1) peningkatan oksidasi dan inaktivasi nitrat oksida endogen (nitric oxidel NO) oleh spesies oksigen reaktif (reactive oxygen species/ ROS) yang mengarah ke fungsional kekurangan NO; (2) peningkatan aktivitas saraf simpatik (3) peningkatan aktifitas angiotensin-converting enzyme (ACE) dan peningkatan kadar renin plasma, angiotensin II dan aldosteron; dan (4) timbal dapat meningkatkan retensi ion natrium. ${ }^{29}$ Paparan timbal dapat mempengaruhi sistem renin-angiotensin dan sistem saraf simpatis pada sel-sel otot jantung dan pembuluh darah. ${ }^{30}$ Hasil penelitian yang dilakukan oleh Alghasham A.A, dkk menyatakan bahwa kadar timbal dalam darah berkorelasi positif dengan peningkatan tekanan darah diastolik dimana kadar timbal dalam darah dapat berpengaruh dan meningkatkan aktifitas angiotensin converting enzim (ACE) ${ }^{31}$ Sejumlah kecil angiotensin dalam plasma darah akan merangsang stres oksidatif yang dapat mengikat nitrat oksida. ${ }^{32}$

Hasil penelitian Sirivarasai J, dkk menyimpulkan bahwa ada hubungan sebab akibat antara paparan timbal dan peningkatan tekanan darah. Paparan timbal kadar rendah yang terkait dengan stres oksidatif dan defisiensi enzim katalase dapat berkontribusi terhadap hipertensi. ${ }^{33}$ Menurut penelitian Araujo M dan Wilcox S.C, stres oksidatif ginjal dapat menjadi penyebab, konsekuensi, atau lebih sering menjadi faktor potensi untuk hipertensi. Peningkatan spesies oksigen reaktif (ROS) di ginjal telah dilaporkan di beberapa kasus hipertensi yang terkait dengan vasokonstriksi ginjal, perubahan fungsi ginjal dan pelepasan renin. ${ }^{34}$ Berdasarkan semua hasil penelitian di atas dapat diketahui bahwa timbal dalam darah akan mempengaruhi sistem saraf dan sistem neuro humoral yang merupakan beberapa pusat kerja yang mengawasi dan mengatur perubahan tekanan darah seperti refleks kemoreseptor, peningkatan aktivitas ACE dalam sistem renin angiostensin, peningkatan stres oksidatif yang dapat mengirim rangsang ke pusat vasomotor di area vasokonstriktor yang akan mengirim rangsang ke pembuluh darah sehingga menyebabkan pengecilan diameter pembuluh darah dan akhirnya akan meningkatkan tekanan darah diastolik. ${ }^{35}$

\section{SIMPULAN}

1. Semua cat yang digunakan di Karoseri Semarang mengandung timbal dengan rata-rata kadar timbal dalam cat sebesar 59,39 ppm. Kadar timbal dalam cat yang digunakan di Karoseri Semarang masih berada di bawah standar kadar timbal dalam cat yang ditetapkan oleh CPSC dan SNI 8011 Tahun 2014 sebesar 600 ppm.

2. Rata-rata kadar timbal dalam udara ruang kerja pengecatan mobil di Karoseri Semarang sebesar $0,002 \mathrm{mg} / \mathrm{m}^{3}$. Kadar timbal udara masih di bawah NAB Permenakertrans sebesar 0,05 ppm.

3. Rata-rata kadar timbal dalam darah pada tenaga kerja bagian painting di Karoseri Semarang sebesar 28,97 $\mu \mathrm{g} / \mathrm{dL}$. Seluruh tenaga kerja bagian painting di Karoseri Semarang telah mengalami keracunan timbal dalam darah berdasarkan standar yang telah ditetapkan oleh WHO, CDC-NIOSH dan CDPH yaitu sebesar $5 \mu \mathrm{g} / \mathrm{dL}$ dan telah memiliki kadar timbal yang tinggi dalam darah ( $>10 \mu \mathrm{g} / \mathrm{dL})$ berdasarkan standar yang telah ditetapkan oleh NHMCR sehingga dapat menimbulkan efek berbahaya bagi fungsi tubuh dan organ orang dewasa mencakup efek tekanan darah.

4. Rata-rata tekanan darah sistolik tenaga kerja bagian painting di Karoseri Semarang sebesar $122,76 \mathrm{mmHg}$. Sebanyak 21 orang $(61,8 \%)$ tenaga kerja memiliki tekanan darah sistolik tidak normal berdasarkan standar yang telah ditetapkan oleh CDC yaitu $\geq 120 \mathrm{mmHg}$.

5. Rata-rata tekanan darah diastolik tenaga kerja bagian painting di Karoseri Semarang adalah sebesar 79,06 mmHg. Sebanyak 19 orang $(55,9 \%)$ tenaga kerja memiliki tekanan darah diastolik tidak 
normal berdasarkan standar yang telah ditetapkan oleh CDC yaitu $\geq 80 \mathrm{mmHg}$.

6. Tidak ada hubungan yang bermakna antara kadar timbal dalam darah dengan tekanan darah sistolik pada tenaga kerja di Karoseri Semarang (nilai $p>0,0465, \mathrm{PR}=0,777,95 \% \mathrm{CI}=0,47-1,29)$, tidak ada hubungan antara usia dengan tekanan darah sistolik pada tenaga kerja di Karoseri Semarang (nilai- $p=0,251 ; \mathrm{PR}=1,477 ; \mathrm{CI}=0,91-2,39$ ). Tidak ada hubungan antara riwayat keturunan hipertensi dengan tekanan darah sistolik pada tenaga kerja di Karoseri Semarang (nilai- $p=0,513 ; \quad \mathrm{PR}=1,684$; $\mathrm{CI}=1,27-2,24)$. Tidak ada hubungan antara indeks massa tubuh dengan tekanan darah sistolik pada tenaga kerja di Karoseri Semarang (nilai- $p=0,627$; $\mathrm{PR}=1,265 ; \mathrm{CI}=0,80-2,33$ ). Tidak ada hubungan antara kebiasaan merokok dengan tekanan darah sistolik pada tenaga kerja di Karoseri Semarang (nilai- $p=0,427 ; \mathrm{PR}=0,908 ; \mathrm{CI}=0,45-1,83$ ). Tidak ada hubungan antara kebiasaan konsumsi alkohol dengan tekanan darah sistolik pada tenaga kerja di Karoseri Semarang (nilai- $p=1,000 ; \quad \mathrm{PR}=2,551$; $\mathrm{CI}=0,94-6,95)$. Tidak ada hubungan antara kebiasaan berolahraga dengan tekanan darah sistolik pada tenaga kerja di Karoseri Semarang (nilai- $p=0,704 ; \mathrm{PR}=1,200 ; \mathrm{CI}=0,71-2,04$ ).

7. Ada hubungan yang bermakna antara kadar timbal dalam darah dengan tekanan darah diastolik pada tenaga kerja di Karoseri Semarang (nilai $p<0,030$, $\mathrm{PR}=2,55,95 \% \mathrm{CI}=0,94-6,95)$, tidak ada hubungan antara usia dengan tekanan darah diastolik pada tenaga kerja di Karoseri Semarang (nilai- $p=0,451$; $\mathrm{PR}=1,400 ; \mathrm{CI}=0,79-2,48)$. Tidak ada hubungan antara riwayat keturunan hipertensi dengan tekanan darah diastolik pada tenaga kerja di Karoseri Semarang (nilai- $p=0,492 ; \quad \mathrm{PR}=1,882$; $\mathrm{CI}=1,36-2,61$ ). Tidak ada hubungan antara indeks massa tubuh dengan tekanan darah diastolik pada tenaga kerja di Karoseri Semarang (nilai- $p=1,000$; $\mathrm{PR}=1,088 ; \mathrm{CI}=0,49-2,39$ ). Tidak ada hubungan antara kebiasaan merokok dengan tekanan darah diastolik pada tenaga kerja di Karoseri Semarang (nilai- $p=0,240 ; \mathrm{PR}=0,617 ; \mathrm{CI}=0,36-1,06$ ). Tidak ada hubungan antara kebiasaan konsumsi alkohol dengan tekanan darah diastolik pada tenaga kerja di Karoseri Semarang (nilai- $p=0,426$; $\mathrm{PR}=1,378$; $\mathrm{CI}=0,76-2,49)$. Tidak ada hubungan antara kebiasaan berolahraga dengan tekanan darah diastolik pada tenaga kerja di Karoseri Semarang (nilai- $p=1,000 ; \mathrm{PR}=1,108 ; \mathrm{CI}=0,59-2,07$ ).

\section{SARAN/REKOMENDASI:}

1. Diharapkan seluruh tenaga kerja di Karoseri Semarang diharapkan agar dapat melakukan usaha-usaha mengurangi paparan terhadap timbal, melakukan pemeriksaan kesehatan secara berkala khususnya pemeriksaan kadar timbal dalam darah dan pemeriksaan tekanan darah serta melakukan terapi keracunan timbal dengan menggunakan chelating agent
2. Diharapkan kepada stakeholder perusahaan dan instansi pemerintah bidang kesehatan agar dapat melakukan pengambilan kebijakan yang tepat guna mengurangi paparan timbal terhadap tenaga kerja.

\section{DAFTAR PUSTAKA}

1 WHO. Exposure to lead: A major public health concern. preventing disease through healthy environments. Public health and environment. 2010. Available from: URL: http://www.who.int/ipcs/ features/lead.pdf.

2 Ismawati Y, Primanti A, Brosché S, Clark S, Weinberg J, Denney V. Laporan nasional timbal dalam cat enamel rumah tangga di Indonesia. Denpasar: Balifokus; 2013.

3 U.S. Departemen of health and human services. Lead toxicity. Atlanta. ATSDR; 2010.

4 NHMCR. Review of blood lead level guidelines. Government of South Australia: Department for Health and Ageing; 2016. Available from: URL: https://www.sahealth.sa.gov.au/wps/wcm/connect/ $42 \mathrm{f} 4440048$ 734e50cdffd48c28c225a/NHMRC + Lead+Level+Guidelines+FAQs+FINAL $\% 5$ B $1 \% 5$ D.pdf?MOD $=$ AJPERES\&CACHEID $=42 \mathrm{f} 4440048$ $734 \mathrm{e} 50 \mathrm{bcdffd} 48 \mathrm{c} 28 \mathrm{c} 225 \mathrm{a}$.

5 CDC. High Blood Pressure Fact Sheet. Clifton Road Atlanta, USA. Februari 2015. Available from:

URL: http://www.cdc.gov/dhdsp/data_statistics/ fact_sheets/fs_bloodpressure.htm.

6 WHO. Blood pressure. Global health observatory (GHO) data. WHO; 2016. Available from: URL: http:// www.who.int/gho/ncd/risk factors/ blood pressure prevalence/en/.

7 Kementerian Kesehatan. Hipertensi. Pusat data dan informasi Kementerian Kesehatan RI. Jakarta; 2014.

8 Dinas Kesehatan Jawa Tengah. Profil Kesehatan Provinsi Jawa Tengah tahun 2012. Semarang. 2013.

9 Muliyadi, Mukono, Notopuro H. Paparan timbal udara terhadap timbal darah, Jurnal Kesehatan Masyarakat. KEMAS 2015; 11(1): 87-95.

10 IPCS. Inorganic lead. Geneva, World Health Organization, International Programme on Chemical Safety (Environmental Health Criteria 165; 1995. Available from: URL:http://www. inchem.org/ documents/ehc/ehc/ehc165.htm).

11 Fenga C, Cacciola A, Martino LB, Calderaro SL, Di Nola C, Verzera A, et al. Relationship of blood lead levels to blood pressure in exhaust battery storage workers. Industrial Health.2006;44:304-9.

12 Sastroasmoro S, Ismael S. Dasar-dasar metodologi penelitian klinis. Edisi 4. Jakarta: Sagung Seto; 2011. 
13 Adib M. Cara mudah memahami dan menghindari hipertensi, jantung dan stroke. Yogyakarta: Dian Loka; 2009.

14 Irianto, DP. Panduan gizi lengkap keluarga dan olahragawa. Yogyakarta; CV. Andi Offset; 2007.

15 Supariasa IDN, Bakri B, Fajar I. Penilaian status gizi. Jakarta: Penerbit Buku Kedokteran EGC; 2002.

16 Lemeshow S, Hosmer D, Klar J, Lwanga S. Besar sampel dalam penelitian kesehatan. Yogyakarta: Gajah Mada University Press; 1997.

17 NSW Government. Spray pengecatan and powder coating code of practice. Australia: Safe Work Australia; 2015.

18 Badan Standardisasi Nasional. Standar nasional Indonesia cat dekoratif berbasis pelarut organik. Standar Nasional Indonesia; SNI-8011:2014.

19 NSW Government. Spray painting and powder coating code of practice. Australia: Safe Work Australia; 2015.

20 WHO-UNEP. Operational framework global alliance to eliminate lead paint. WHO-UNEP. Maret 2011. Available from: URL: https://www. google. $\quad$ co.id/\#q=operational + framework + global + alliance+to+eliminate+lead+paint.

21 Muliyadi, Mukono, Notopuro H. Paparan timbal udara terhadap timbal darah, Jurnal Kesehatan Masyarakat. KEMAS 2015; 11(1): 87-95.

22 WHO. Lead: Assessing the environmental burden of disease at national and local levels. Geneva, World Health Organization (Environmental Burden of Disease Series: 2003 (2). Available from: URL: http://www.who.int/ quantifying ehimpacts/publications/en/ leadebd2.pdf).

23 U.S. Departemen of Health and Human Services. Adult blood lead epidemiology \& surveillance (ables). United States. CDC; 2016.

24 California Departemen of Public Health. Medical guidelines for the lead exposed worker. California. OLPPP; 2009.

25 Palar H. Pencemaran dan toksikologi logam berat. Cetakan 4. Jakarta: Rhineka Cipta; 2012.

26 Hasan W, Pencegahan keracunan timbal kronis pada pekerja dewasa dengan suplemen kalsium. Makara, Kesehatan Juni 2012; 16(1): 1-8.

27 Nawrot TS, Thijs L, Hond DEM, Roels HA dan Staessen JA. An Epidemiological re-appraisal of the association between blood pressure and blood lead: a meta-analysis. Journal of Human Hypertension (2002); 16(123-131).

28 Turak O, Canpolat U, Isleyen A, Mendi M, Öksüz F, Özcan F, et al. Relationship between hemoglobin level and blood pressure variability in patients with newly diagnosed untreated essential hypertension. JACC. Oktober 2013; 62 (18).
29 Vaziri, ND. Pathogenesis of lead-induced hypertension: role of oxidative stress. Journal Hypertens Suppl. Juni 2002; 20(3):15-20.

30 Boscolo P, Carmignani. Neurohumoral Blood Pressure Regulation in Lead Exposure. Environmental Health Perspectives. 1988; 78(101106).

31 Alghasham A.A, Meki AR dan Ismail HAS. Association of Blood Lead level with Elevated Blood Pressure in Hypertensive Patients. Int $\mathrm{J}$ Health Sci (Qassim). Jan 2011; 5(1): 17-27.

32 Romero J.C. dan Reckelhoff J.F. Oxidative stress may explain how hypertension is maintained by normal levels of angiotensin II. Orxaizdialitainve $\mathbf{J}$ osutrrensas laonfd $M$ heydpiecratle annsido nBiological Research (2000); 33(653-660).

33 Sirivarasai J, Kaojarern S, Chanprasertyothin S, Panpunuan P, Petchpoung K, Tatsaneeyapant A, et.al. Environmental lead exposure, catalase gene, and markers of antioxidant and oxidative stress relation to hypertension: an analysis based on the egat study. Hindawi Publishing Corporation. BioMed Research International. 2015.

34 Araujo $M$ dan Wilcox SC. Oxidative stress in hypertension: role of the kidney. Antioxidants \& Redox Signaling. 2014; 20 (1).

35 Masud, Ibnu. Dasar-dasar fisiologi kardiovaskuler. Cetakan I. Jakarta: Penerbit Buku Kedokteran EGC; 1992. 